\title{
Water safety - as the mortgage of stable development of Ukraine
}

\author{
Romashchenko M. ${ }^{1}$, Yatsyuk M. ${ }^{2}$, Shevchuk S. ${ }^{3}$, Shevchenko A. ${ }^{4}$, Danylenko lu. ${ }^{5}$, Matiash T. ${ }^{6}$, \\ Sydorenko $0 .^{7}$ \\ Institute of water problems and melioration of NAAS, Vasylkivska Str., 37, Kyiv, 03022, Ukraine; e-mail: \\ 1mi.romashchenko@gmail.com, ${ }^{2} m v \_y a t s i u k @ u k r . n e t, \quad{ }^{3}$ sergey_shevchuk_@ukr.net,

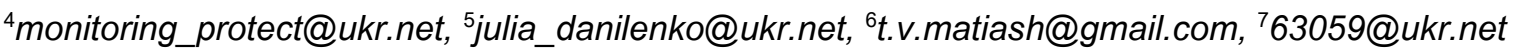

The purpose. Substantiation of necessity of achievement of comprehensible level of water safety of Ukraine as strategic purpose of national water policy. Methods. Analysis, synthesis, generalization. Results. Water safety consists in maintenance of equal right to drinking water and sanitary for each person. Ukraine is one of the least provided by own water resources countries in Europe by specific quantity of local flow. In shallow year it has for 1 inhabitant only 0,6 thousand $\mathrm{m}^{3}$, and in view of transit drainage $-1,2$ thousand $\mathrm{m}^{3}$. Water availability with local water resources on separate areas of the state differs almost in 60 times. Accessible to use stocks of surface waters are non-uniformly distributed on territory. More than half of water resources are concentrated in basin of river Danube where the water needs do not exceed $5 \%$. Use of potential of irrigation and drainage systems is extremely unsatisfactory: from available 2,17 million hectares of irrigated lands only 500 thousand hectares are actually watered, and 2-side regulation is carried out only for 250 thousand hectares of 3,2 million hectares of available sewed lands. In sector of aquatic ecosystems overall regularity of process of deterioration of water of river drainages is registered. The problem of formation of appropriate state of water safety of Ukraine at legislative level is not settled and demands the further scientific substantiation and legal maintenance. Conclusions. State of water safety of Ukraine at national and sectoral levels is extremely unsatisfactory. Therefore achievement of due level of water safety of Ukraine is an overall objective of national water policy of Ukraine and should be fixed in "Water strategy of Ukraine». The main tool of achieving this purpose should become the integrated water resources management according to basin principle.

Key words: water safety, national water policy, water strategy of Ukraine, water resources.

https://doi.org/10.31073/agrovisnyk201811-22

According to global estimates the amount of suitable water for human consumption and functioning of most terrestrial ecosystems on the planet is 35 million $\mathrm{km}^{3}$ that is only $2.5 \%$ of the total Earth water resources, of which two- thirds is contained in glaciers and snow cover, making them virtually inaccessible for widespread use [1].

The scarcity of available fresh water resources and their uneven spatial distribution over the world, as well as the increase of water consumption, water pollution and climate change are gradually transformed into global problems related to drinking water shortage, from the one side, and threats of regional water conflicts, from the other side [2].

That is the reason why, starting from the beginning of the XXI century, a concept of "water security" has been coming into widespread acceptance and is a cornerstone of the modern vision of the future of our planet. Water security can be defined as "the availability of a suitable quantity and quality of water for health, life activities, ecosystems and production, coupled with an acceptable level of water- related risks to people, environment and economy" [3]. So, achieving an appropriate level of water security is not only an ultimate objective of water policies to growing number of countries, but also one of the main goals in sustainable development of mankind in general.

As defined by the International Water Management Institute [4] the concept of water security is an integral part of the agenda to address global problems. The concept recognizes the importance of synergy between water- dependent sectors and the need to strengthen these links in order to create an effective water management and establish appropriate policies.

Global Water Partnership [5,6] declares that the concept of water security is based on the recognition of the key role of water to all areas of human development: food security, health, poverty reduction and sustainable development in agriculture, industry and energy sectors. 
The state of water resources and water supply for population and industries of Ukraine remains a major threat to the national security. The severity of this problem arises from the fact that Ukraine is one of the least sustainable countries in Europe regarding its own water resources having the intensity of local runoff in dry years per capita only 0.6 thousand $\mathrm{m}^{3}$, and including the transit flow -1.2 thousand $\mathrm{m}^{3}$ [7]. (Fig.1).

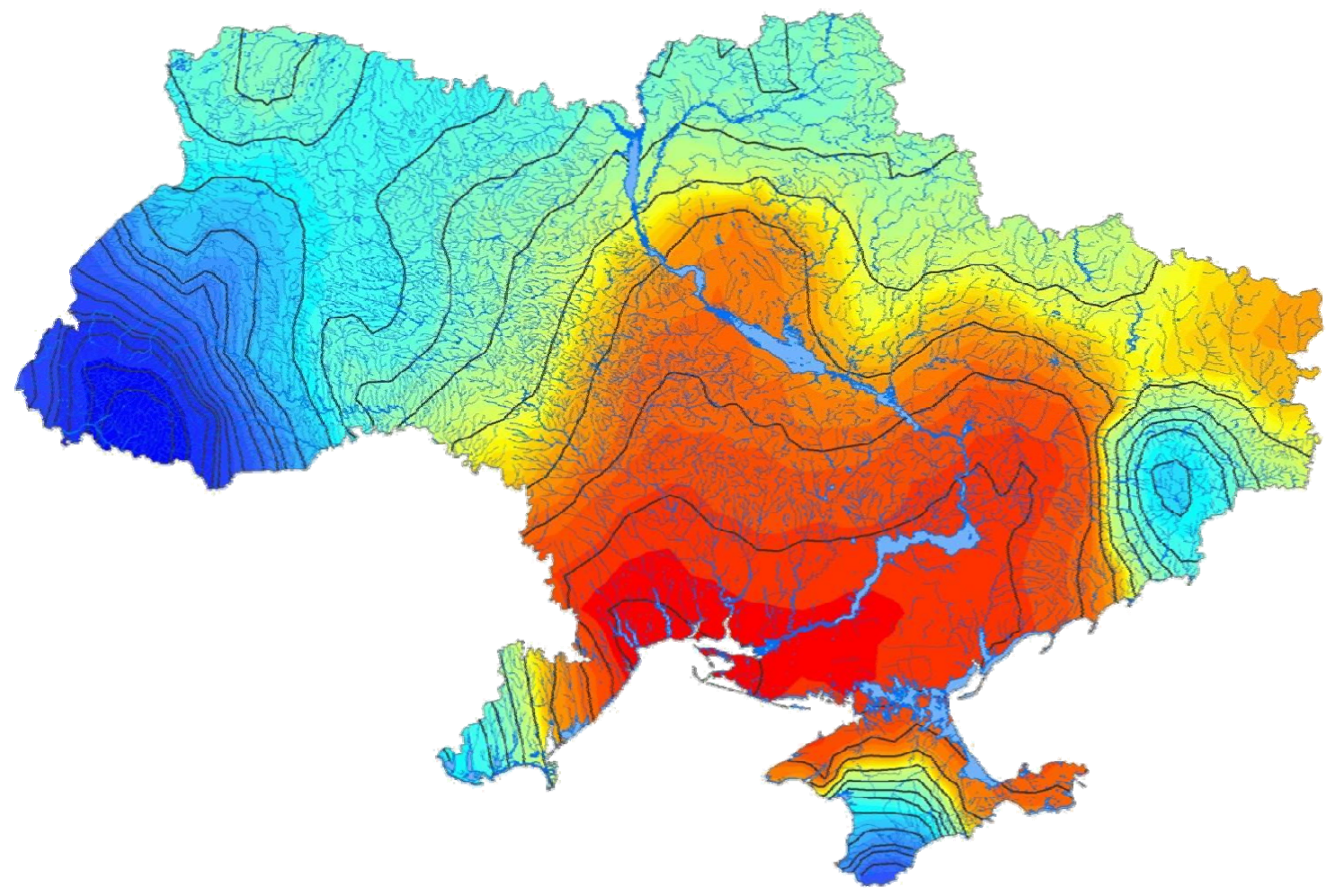

Fig. 1 Distribution of the average rate of runoff over the territory of Ukraine

The average long-term runoff in Ukraine is $54.7 \mathrm{~km}^{3}$ a year, and it varies in different years by dryness $50.9 \mathrm{~km}^{3}$ - in average year, $38.8 \mathrm{~km}^{3}$ - in dry years and $25.6 \mathrm{~km}^{3}$ - in very dry years. (Tab. 1)

Table 1. Water resources of Ukraine

\begin{tabular}{|c|c|c|}
\hline \multirow[t]{2}{*}{ Resources } & \multicolumn{2}{|c|}{$\begin{array}{l}\text { Water resources by year by water } \\
\text { content km }\end{array}$} \\
\hline & Medium & Low water \\
\hline Inflow of transit river runoff & $157,4^{*} / 37,3^{* *}$ & $121,7^{*} / 26,2$ \\
\hline Local river runoff & 52,4 & 29,7 \\
\hline Total resources of river runoff & $209,8 / 87,1$ & $151,4 / 55,9$ \\
\hline Predicted resources of ground waters & 22,5 & 22,5 \\
\hline $\begin{array}{l}\text { Including those, which are not involved in the surface } \\
\text { runoff }\end{array}$ & 7,0 & 7,0 \\
\hline Total resources of fresh water & $216,8 / 94,1$ & $158,4 / 62,9$ \\
\hline
\end{tabular}

The difference in the availability of local water resources between some regions of the country is very significant, and can be 60 times as much from $0.14 \mathrm{~km}^{3}$ a year in Kherson region against $7.92 \mathrm{~km}^{3}$ a year - in Transcarpathian region.

The surface water available for use is very unevenly allocated across the country. More than half of the water is concentrated in the Danube basin, where water demand does not exceed $5 \%$. To improve the water 
supply in water-stressed regions more than 1,160 reservoirs with a total storage capacity of about $55 \mathrm{~km}^{3}$ have been constructed in Ukraine. The network of supply canals (over 1.0 thousand $\mathrm{km}$ ) and water pipelines (over 2.0 thousand $\mathrm{km}$ ) is also well-developed. This enables to redistribute respectively 3 and $12 \mathrm{~km}^{3}$ of water annually through the territory of the country [7].

River regularization of the main watercourses of Ukraine made it possible to redistribute the runoff and to meet the needs of water consumers and water users, but turned the rivers into significantly altered water bodies with poor ecological status and low potential of self-purification. It is demonstrated by the lack of any significant improvement in the quality of water in the Dnieper or other rivers despite an intense reduction in water intake (more than three fold for the last 25 years: from $30 \mathrm{~km}^{3}$ in 1990 up to $<9.7 \mathrm{~km}^{3}$ in 2015) and the discharges of sewage waters (from $18 \mathrm{~km}^{3}$ in the 1990s to $5.3 \mathrm{~km}^{3}$ in 2015) in different sectors of the country's economy. The runoff regulation is accompanied by the emergence of a number of environmental problems related to the functioning of water bodies. In particular, the well-known consequences of the construction of hydroelectric power stations are the creation of hydrotechnical structures of varying complexity and purpose, the operation of which gives rise to the hydromorphological changes in the rivers (the loss of flow speed, the rise of water levels, the accumulation of significant volumes of bottom sediments, flooding of large areas for reservoir beds formation and so on) that in turn causes the degradation of river ecosystems and the loss of their ability to self-purification as well as the significant pollution of surface waters. That also affects the qualitative and quantitative state of biological resources and leads to the flooding of adjacent areas.

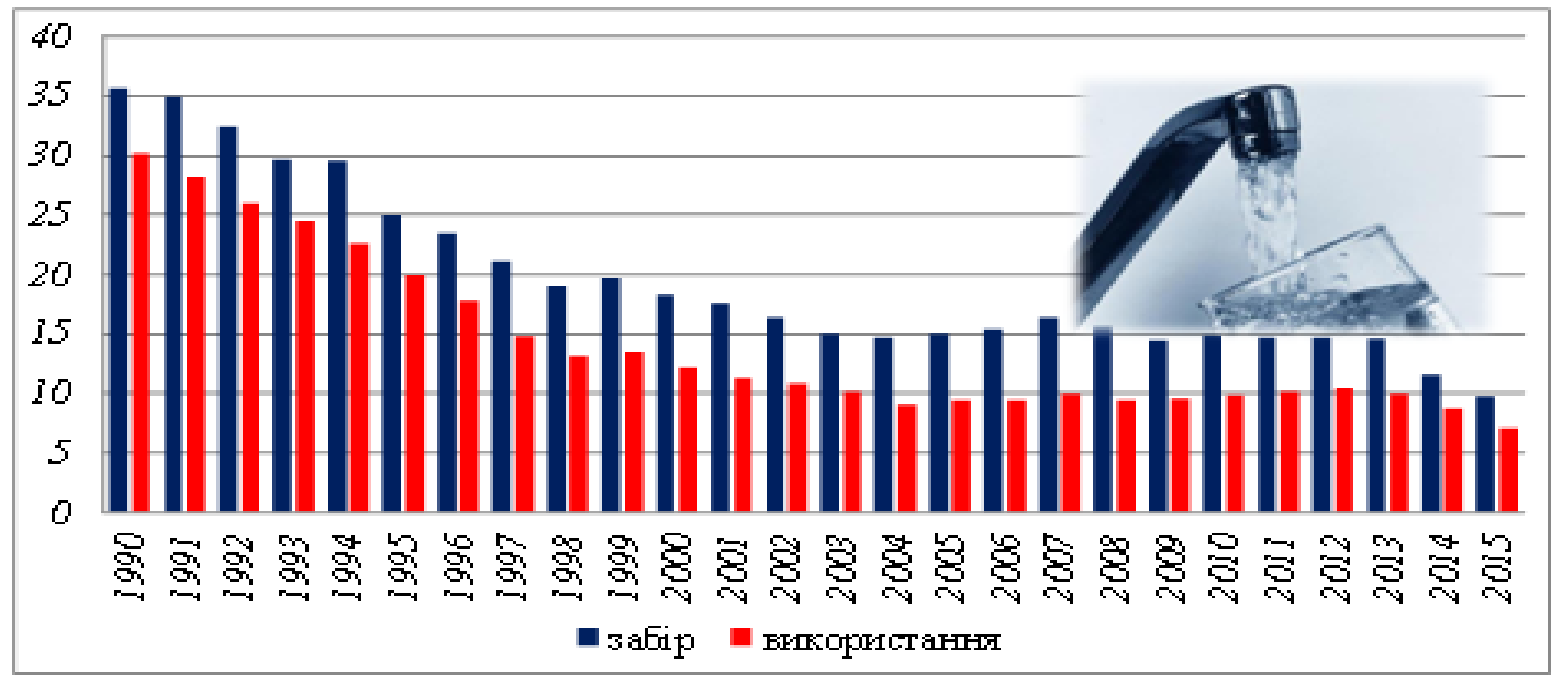

Fig. 2. Water abstraction and water use in Ukraine, billion $\mathrm{m}^{3}$ Following a long (more than $\mathbf{3 0}$ years) tendency to warming and rising the

frequency and duration of droughts (especially for the last ten years) as well as to the reduction in river flow, the issue of regulating the operation regimes of reservoirs and distributing the accumulated water to provide the population and economy with water in accordance with the approved priorities is becoming more and more a difficult task. In the recent years, characterized by low water content, the water accumulated in the reservoirs is not only enough for environmental but even for regulating releases.

Annually in Ukraine about $11 \mathrm{~km}^{3}$ of water are extracted for the needs of water supply and economic sectors, including about $8 \mathrm{~km}^{3}$ - from surface sources, $2 \mathrm{~km}^{3}$ - from underground sources and up to $1 \mathrm{~km}^{3}-$ sea water [8].

Under the climate change some additional threats to food security are emerging due to the rise of the deficit of annual water balance in a large part of the country and deterioration of the engineering infrastructure of drainage systems as well as the stagnation of the utilization of irrigation and drainage potential [9]. Utilizing the potential of irrigation and drainage systems as a basis for improving natural water supply is unsatisfactory, since from the existing 2.17 million hectares of irrigated land only 500 thousand are actually irrigated while the bilateral water control is exercised only on 250 thousand from the available 3.2 million hectares ofdrained land. That resulted in the disability of reclaimed land to act as a security reserve in food and resources provision of the state in the years of adverse weather conditions. Therefore the task of restoring an effective 
environmentally sustainable utilization of reclaimed land potential, especially irrigation, is one of the priorities of the state policy of Ukraine as well as one of key aspects of the development of the agricultural sector of the economy. Specifically the development of irrigation and drainage sector is considered to be as an objective prerequisite for achieving the annual grain production in the quantity of 80-100 million tons that will enable to turn Ukraine into one of the world food donors.

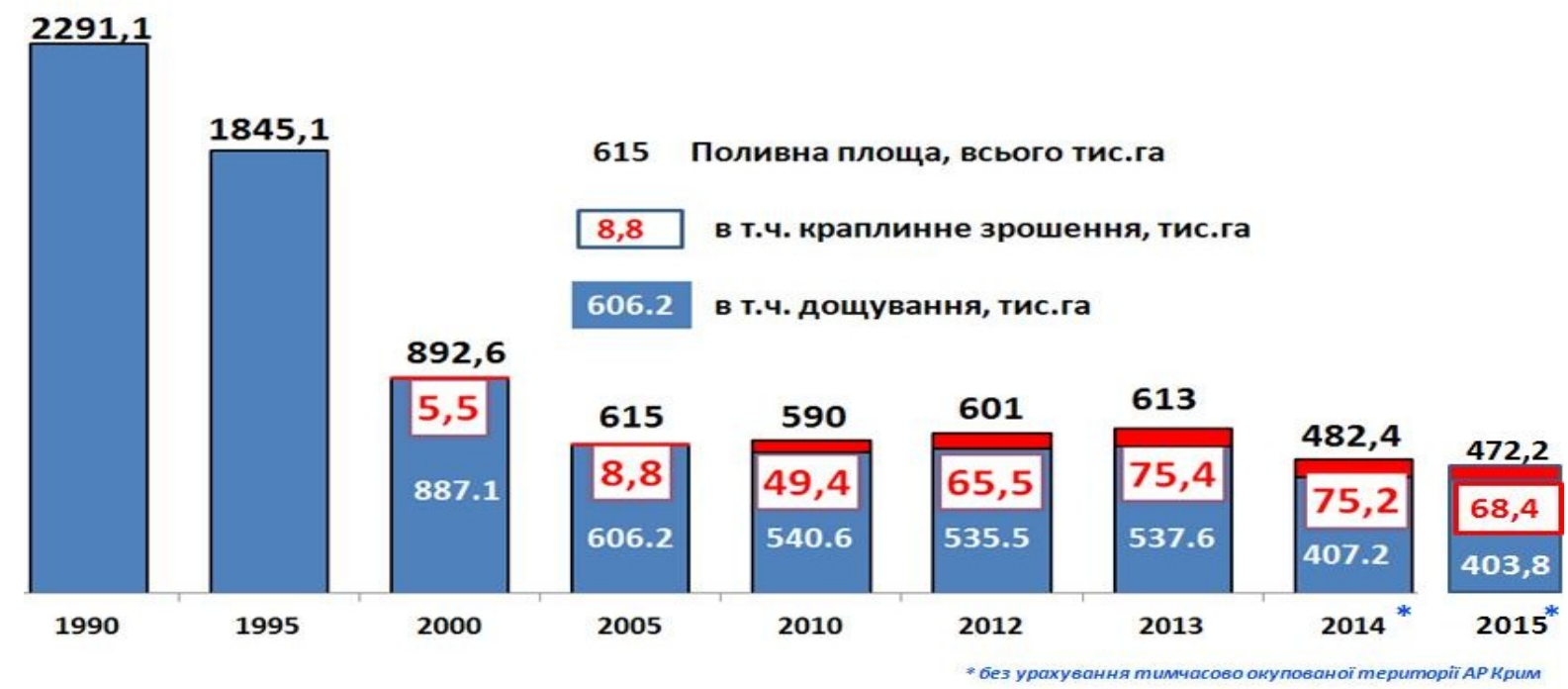

Fig. 3. Actual irrigated area

As concerns the issue of water supply of cities and households the main problem is the insufficient level of centralized water supply and sanitation, since more than 1,300 villages with the populations over 800 thousand people so far use imported water [10] (Tab. 2).

Table 2. Centralized water supply of settlements in Ukraine

\begin{tabular}{|c|c|c|c|c|c|c|c|c|}
\hline \multirow[t]{2}{*}{ Settlements } & \multirow{2}{*}{$\begin{array}{l}\text { Population, } \quad, 000 \\
\text { people }\end{array}$} & \multicolumn{7}{|c|}{ Years } \\
\hline & & 2000 & 2009 & 2010 & 2011 & 2002 & 2013 & 2014 \\
\hline \multirow[t]{3}{*}{ Towns } & More than 500 & 93 & 91,3 & 99.1 & 99,4 & 99,6 & 99,8 & 89,8 \\
\hline & $100-500$ & 86 & & & & & & \\
\hline & $20-100$ & 75 & & & & & & \\
\hline Small towns & 20 & & 87,1 & 87,1 & 87,0 & 85,9 & 85,9 & 68,8 \\
\hline $\begin{array}{l}\text { Rural } \\
\text { settlements }\end{array}$ & Less than 20 & 26 & 22,1 & 22,0 & 22,0 & 22,1 & 22,1 & 17,2 \\
\hline
\end{tabular}

Traditional energy production in Ukraine (at TPP or NPP) is extremely water- intensive process. In 2015, the sector of thermal power used for its own needs 2,400 million cubic meters of water, the sector of nuclear power - 327.8 million cubic meters, 106,000 million cubic meters of water ran through the turbines of HPP (the runoff of the Dnieper River - the main waterway of Ukraine in a dry year is 30,000 million cubic meters); but only about 11 billion kilowatt-hours were produced, which indicates the inefficient use of water resources in the electricity generation industry. 


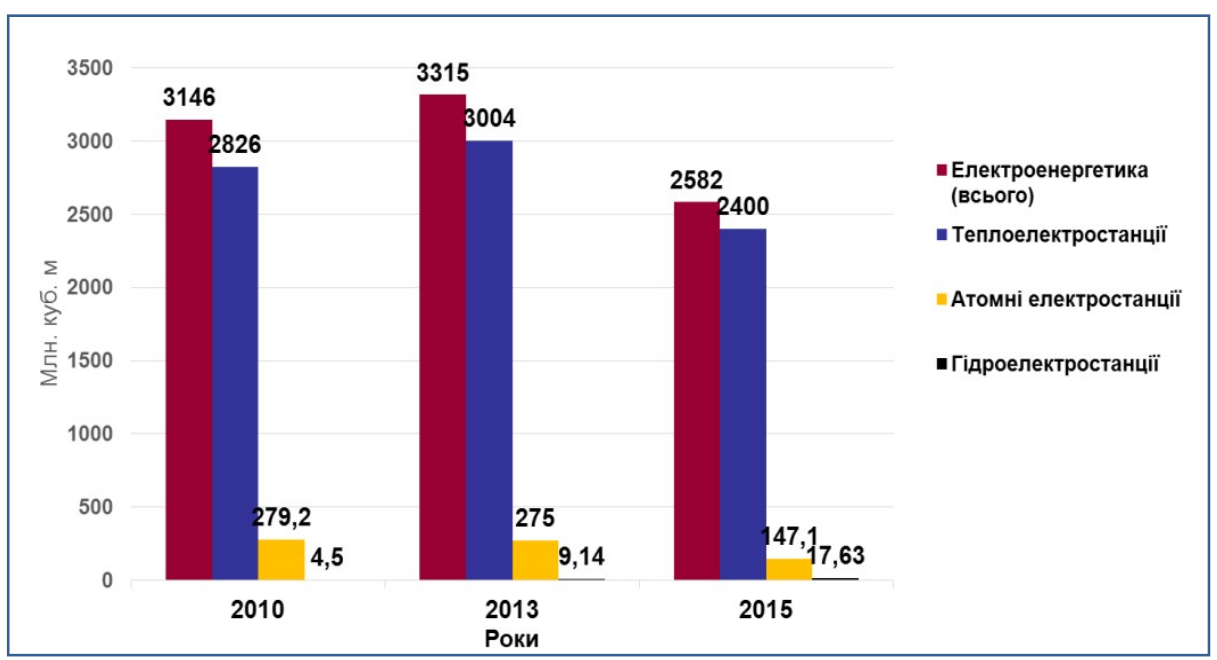

Fig. 4. Total water abstraction from natural water bodies for the production of electricity, million $\mathbf{m}^{3}$

Thermal and nuclear power plants that require large amounts of water for electricity generation and cooling turbines and reactors pose significant risks to water security. The operation of direct-cooling systems of thermal power plants, which requires the significant amounts of water and leads to a decrease in the runoff of water bodies and deterioration of water quality (thermal pollution), is causing concern. In dry (low water) years, the operation of thermal and nuclear power plants greatly steps up the "competition" for water resources in Ukraine. Due to the limited use of water resources, the issue of potential development and completion with new blocks of existing NPPs deserves special attention. Thus, in 2007, under the conditions of drought, the issue of limiting access to water for drinking needs and agriculture in the basin of the Southern Bug was acutely due to the complete regulation of the runoff in the Oleksandrivske reservoir to ensure the safe operation of the South-Ukrainian NPP.

In aquatic ecosystems sector it can be observed a general trend to the deterioration of water quality in river basin, in other words -metamorphization of chemical water composition (from calcium bicarbonate water to sulphate sodium chloride water). The load on the aquatic ecosystems of river basins (the ratio of water intake in the basin to the volume of actual runoff) in most basins is above the environmentally safe level and in the basin of the Siversky Donets River it is critical and accounts for 42 percent [7] (Tab. 3).

Table 3. Water abstraction from the river basins of Ukraine

\begin{tabular}{|l|l|l|l|l|l|l|}
\hline № & River basin & $\begin{array}{l}\text { Catchment } \\
\text { area, } \mathrm{km}^{2}\end{array}$ & $\begin{array}{l}\text { Natural } \\
\text { runoff, } \mathrm{km}^{3}\end{array}$ & $\begin{array}{l}\text { Actual runoff, } \\
\mathrm{km}^{3}\end{array}$ & \multicolumn{2}{|l|}{ Abstraction } \\
\cline { 6 - 8 } & & 540000 & 53,5 & 41,9 & 8,68 & 20,7 \\
\hline 1 & Dnieper & 72100 & 10,0 & 8,66 & 0,62 & 7,1 \\
\hline 2 & Dniester & 52400 & 3,69 & 3,47 & 1,45 & 41,8 \\
\hline 3 & Siversky Donets & 63700 & 3,02 & 2,83 & 0,39 & 13,8 \\
\hline 4 & Southern Bug & & & & & \\
\hline
\end{tabular}

The modern system of river runoff and water quality monitoring requires to increase a number of monitoring posts and update their and laboratory equipment, computerize the data collection and information management service; develop new mechanisms for accessing the information for the rapid adoption of management decisions 


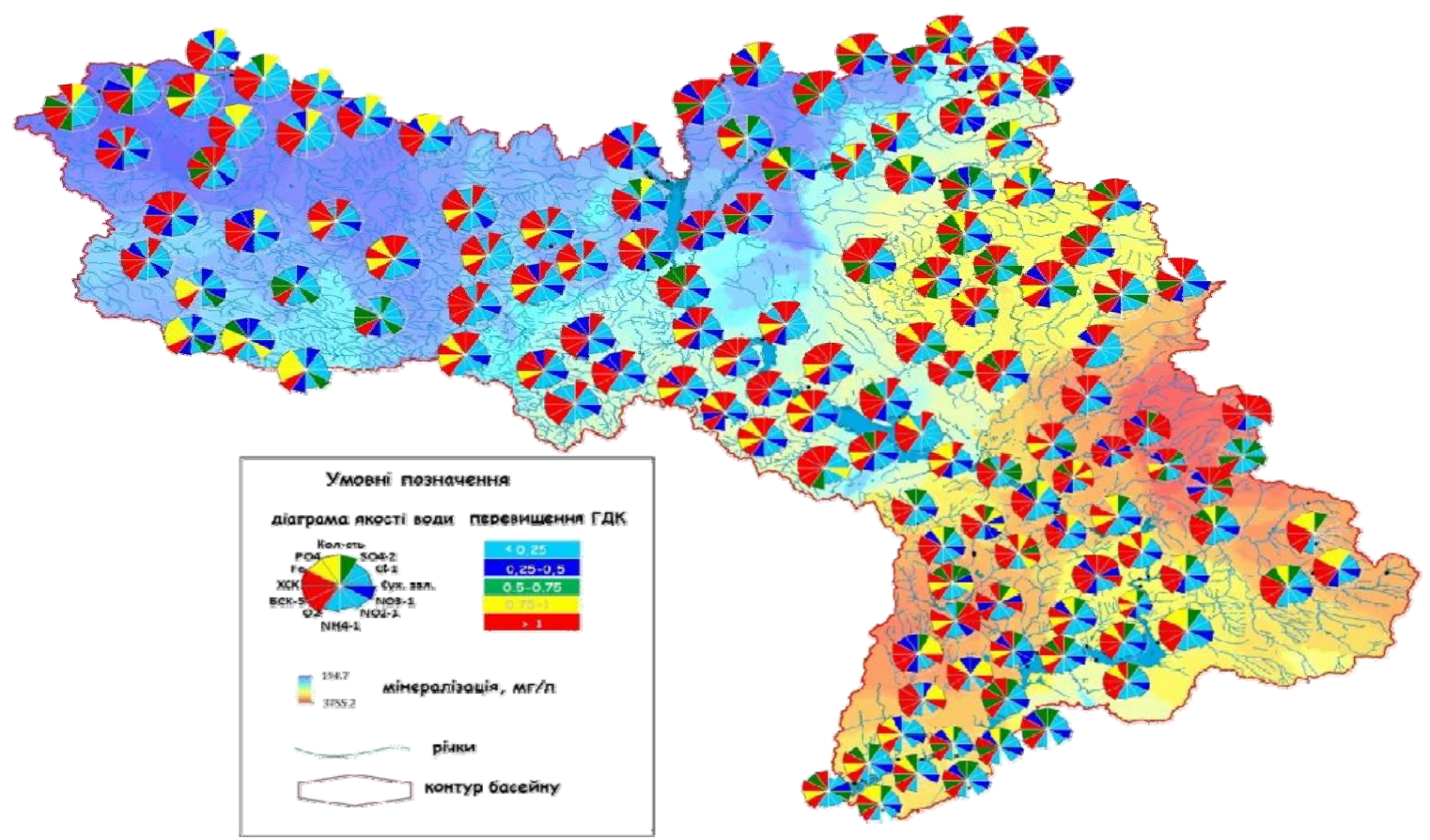

Fig. 5. Map of indicators of surface water quality in the Dnieper River basin.

The problems related to protection against the harmful effects of water have not solved yet to the full extend. The third of the country s population regularly suffers from floods and waterlogging. The rivers of the Carpathian region are characterized by the increased flood hazard. About $11 \%$ of the territory of Ukraine (over 540 cities and towns, more than 450 villages) are prone to subsoil waterlogging.

Despite a large number of water and ecological problems that really affect the national security of Ukraine, the problem of establishing a proper state of water security in Ukraine at the legislative level as an important component of national security has not been resolved yet. It till requires further scientific rationale and regulatory support as a strategic goal of the countrys sustainable development. Ukraine has not developed and adopted the water strategy for Ukraine yet, and subsequently the strategic goals of the state water policy and the objectives to achieve it have not been defined and formed either for a long- or near-term prospect.

The first positive step towards solving this problem was holding the National Water Dialogue in March 2017 at which the issue of the necessity of water strategy development for Ukraine as a basis for the formation of water policy of the country was raised [10].

According to the proposed evaluation system [8] (ADB, 2013) the level of water security of Ukraine is defined as threatening due to a partial legislative support in the field of water management and environmental protection, insufficient public investment and failure to abide by the rules and laws in this sector.

In light of this, achieving an acceptable level of water security in Ukraine is proposed to determine as a strategic objective of national water policy. Thus the national targets and indicators of water safety should be specified in view of the obligations undertaken by Ukraine under the Association Agreement between Ukraine and the European Union, the provisions of the EU Water Framework Directive 2000/60/EC and national targeted indicates to the Protocol on Water and Health. The strategic goals and objectives of the national environmental policy, the objectives of the "State target program of water management and environmental rehabilitation of the Dnieper River basin for the period until 2021 year" as well as the provisions of the recently adopted Law of Ukraine "On amendments to some legislative acts of Ukraine concerning the implementation of integrated approaches to water management by basin principle" should be also taken into account for this purpose. Water Strategy of Ukraine should become the main legal document that defines the principles of the new water policy of Ukraine.

Integrated water management by the basin principle should be the main instrument of timely and proper fulfilling the tasks to achieve a good level of water security, subject to an adequate scientific support for the conceptual and applied aspects of the management[10]. 
Despite the significant scientific achievements on the integrated water management, its implementation in practice just as it is will not allow to achieve a proper level of water security in Ukraine without carrying out a complex of additional research.

To form the scientific principles of water security of Ukraine in terms of climate change the Presidium of the National Academy of Agrarian Sciences of Ukraine proposed the Presidiums of the National Academy of Sciences and National Academy of Medical Sciences to co-develop the concept of the scientific and technical program for 2018-2025 years "Scientific principles of ensuring water security of Ukraine", the main areas of which should include:

- developing scientific and methodological, organizational and legal as well as legislative principles of the formation of water security of the country in terms of climate change and growing water stress;

- developing scientific and methodological foundations to improve the criteria and indicators of national and sectorial water securities, establishing and performing their monitoring for effective water management;

- $\quad$ studying the water cycle processes and developing environmentally-friendly and economically reasonable methods of water extraction from the natural hydrologic cycle to meet the needs of social development;

- $\quad$ developing water use technology that provides a decrease in specific water consumption per unit of goods produced in all sectors of the economy.

In general, for today the issue of the development of legislative, organizational, legal, scientific and methodological bases for the formation of water security of the country in terms of climate change and its impact on environmental and economic security of the state, becomes a key aspect and requires to be one of the national security issues followed by the further refining of scientifically grounded management decisions at the national level. Therefore, the Presidium of the National Academy of Agrarian Sciences of Ukraine appealed to the National Security and Defense Council of Ukraine with the proposal to consider at a meeting of NSDC the question "On the state and objectives for improving water security in Ukraine" as one of the priority issues of national security of Ukraine.

In addition, it has been proposed to put in the list of the main goals of the "Sustainable Development Strategy of Ukraine" the task of achieving a good level of water security in Ukraine up to 2050.

In addition, it was proposed to include in the list of the main goals of the sustainable development of the Strategy of Sustainable Development of Ukraine the task of achieving a good state of water security in Ukraine up to 2050.

It can be possible subject to a set of measures to be implemented, the main of which are:

- $\quad$ to harmonize and implement water legislation in accordance with the Association Agreement between Ukraine and the EU, in particular, to implement the integrated river basin management, which is the way of providing water security;

- $\quad$ to review, optimize and update the water resources monitoring system (in accordance with the requirements of the EU Water Framework Directive);

- $\quad$ to state the provision of water and hygiene as a priority number 1 in the allocation of available water resources among the various water users and develop the necessary mechanisms (including economic ones) to implement this priority in practice;

- $\quad$ to develop and implement the Plan of Implementation of the Protocol on Water and Health, taking into account national targets and indicators;

- $\quad$ to approve and implement methodological recommendations for the preparation of River Basin Management Plans (RBMPs), stimulate the development and implementation of RBMPs taking into account both flood and draught risk managements that are relevant for the whole of Ukraine;

- $\quad$ to review the state target water programs, in particular, "Drinking Water of Ukraine", "Program for the Development of Water Management and Ecological Improvement of the Dnieper River Basin for the period up to $2021 ")$, identify the priority areas and measures and ensure an appropriate public funding using the co- financing mechanism for interested parties. 


\section{Conclusions}

State of water safety of Ukraine at national and sectoral levels is extremely unsatisfactory. Therefore achievement of due level of water safety of Ukraine is an overall objective of national water policy of Ukraine and should be fixed in «Water strategy of Ukraine». The main tool of achieving this purpose should become the integrated water resources management according to basin principle.

\section{References}

1. Aziatskyi bank rozvytku. Rozvytok vodnykh resursiv v Azii. Perspektyvy 2013 roku: otsinka vodnoi bezpeky v Azii ta Tykhookeanskomu rehioni. [Asian Development Bank. Development of water resources in Asia. Outlook 2013: Assessing Water Security in Asia and the Pacific]. Mandaluionh, Filippiny: Aziatskyi bank rozvytku. 2013. URL: https://www.adb.org/sites/default/files/publication/30190/asian-water-developmentoutlook-2013.pdf [In Ukrainian].

2. FAO. Stan zemelnykh ta vodnykh resursiv u sviti dlia prodovolstva ta silskoho hospodarstva (SOLAW) - Upravlinnia ryzykamy. Prodovolcha ta silskohospodarska Orhanizatsii Obiednanykh Natsii, Rym i Oskan, London. [FAO State of the world's land and water resources for food and agriculture (SOLAW) - Risk management. United Nations Food and Agriculture Organization, Rome and Oskan, London]. URL: http://www.fao.org/docrep/017/i1688e/i1688e.pdf [In Ukrainian].

3. Hrei D., Sadoff K. (2007). Tonuty chy plysty? Vodna bezpeka dlia zrostannia ta rozvytku. [To drown or swim? Water security for growth and development]. Vodna polityka. Ofitsiinyi zhurnal Vsesvitnoi Vodnoi Rady. T. 9, No 6. P. 545 - 570. URL: http://cip.management.dal.ca [In Ukrainian]

4. Stratehiia 2014 - 2018 rr. Rishennia dlia svitovoi vodnoi bezpeky. [Strategy 2014-2018 World Water Security Solutions]. IWMI. 2014. 32 p. URL: http://www.iwmi.cgiar.org/About IWMI/PDF/iwmistrategy-2014 2018.pdf [In Ukrainian].

5. Hlobalna Vodna Stratehiia do 2020 roku. [Global Water Strategy by 2020]. Svitova vodna bezpeka. 2014. 28 p. URL: https://www.gwp.org/globalassets/global/about-gwp/ strategicdocuments/gwp_strategy_towards_2020.pdf [In Ukrainian].

6. Sadoff K., Myuller M. (2009). Upravlenie vodnimi resursami, vodokhozyaystvennaya bezopasnost' i adaptatsiya k izmeneniyu klimata: pervye vozdeystviya i neobkhodimye otvetnye mery. Global'noe vodnoe partnerstvo. Tekhnicheskiy komitet. [Water management, water security and climate change adaptation: first impacts and necessary responses. Global Water Partnership. Technical committee]. URL: https://www.gwp.org/globalassets /global/toolbox/publications/background-papers/14-water-managementwatersecurity-and-climate-change-adaptation.-early-impactsand-essential-responses-2009-russian.pdf [In Russian].

7. Romashchenko M.I., Khvesyk M.A., Mykhailov Yu.O. et al. (2015). Vodna stratehiia Ukrainy na period do 2025 roku (naukovi osnovy). [Water strategy of Ukraine for the period up to 2025 (scientific basis)]. Kyiv. 46 p. [In Ukrainian].

8. Romashchenko M.I., Shevchenko A.M., Liutnytskyi S.M. (2017). Stan ta shliakhy pidvyshchennia vodozabezpechenosti pivdennoho rehionu Ukrainy vodnymy resursamy richky Dunai. [The state and ways of increasing the water supply of the southern region of Ukraine by the water resources of the Danube River]. Melioratsiia i vodne hospodarstvo. No 105. P. 12 - 21. [In Ukrainian].

9. Hadzalo Yu.M., Romashchenko M.I., Hryn Yu.I. (2014). Kontseptsiia vidnovlennia i rozvytku zroshennia v Pivdennomu rehioni Ukrainy. [The Concept of Irrigation Recovery and Development in the Southern Region of Ukraine]. Kyiv. 27 p. [In Ukrainian].

10. Adamenko T.I., Demydenko O.O., Romashchenko M.I. et al. (2016). Pereosmyslennia vodnoi bezpeky dlia Ukrainy. Kyiv. [Re-thinking of water security for Ukraine]. 19 p. [In Ukrainian]. 